\title{
PENGARUH KAUSAL ANTARA UKURAN PERUSAHAAN, NILAI BUKU DAN LIKUIDITAS SAHAM DI BURSA EFEK INDONESIA
}

\author{
Arfa Danil ${ }^{1)}$, Irdha Yusra ${ }^{2)}$ \\ Sekolah Tinggi Ilmu Ekonomi KBP \\ arfadanil@gmail.com \\ irdhayusra@akbpstie.ac.id
}

\begin{abstract}
Basically the most interesting aspect for investors is liquid stocks where the level of liquidity of a stock is driven by transactions carried out on the stock so the more often a stock is traded shows a high level of mobility and the easier the stock is traded. This study aims to examine the effect of firm Size, book value on stock liquidity. The population in this study are companies listed on the Indonesia Stock Exchange (IDX) for the period 20132017. The sampling technique uses a purposive sampling method and based on predetermined criteria a sample of 99 companies has been obtained. Financial report data is obtained from the official IDX website. The analytical method used is panel data regression analysis with the help of application E-Views 8. The initial test done is to test the Chow-Test to decide whether the method of Pooled least square or Fixed effect is used; and Haussman-test testing to decide whether the fixed effect method or random effect can be used. The results of this observation state that firm size does not have a significant effect on stock liquidity, while book value has a significant effect on stock liquidity.
\end{abstract}

Keywords: firm size, book value, liquidity

\section{PENDAHULUAN}

Pasar modal merupakan salah satu alternative bagi perusahaan untuk menghimpun dana dari investor. Dalam melakukan investasi, para investor membutuhkan informasi yang dapat digunakan dalam pengambilan keputusan yang berkaitan dengan pemilihan portofolio investasi mereka. Informasi dapat mengurangi tingkat ketidakpastian yang terjadi, sehingga keputusan yang akan diambil diharapkan sesuai dengan tujuan yang akan dicapai (Lestari \& Sudaryono, 2008)

Aspek yang paling menarik bagi investor adalah saham yang likuid dimana tingkat likuiditas suatu saham didorong oleh transaksi-transaksi yang dilakukan terhadap saham jadi Semakin sering suatu saham ditransaksikan menunjukkan tingkat mobilitas yang tinggi dan semakin mudah saham tersebut diperdagangkan. (Wira, 2012)

Likuiditas saham merupakan ukuran jumlah transaksi suatu saham di pasar modal dalam suatu periode tertentu. Jadi semakin likuid saham maka frekuensi transaksi semakin tinggi (Mulyana, 2011). Likuiditas saham merupakan salah satu faktor penting yang perlu dipertimbangkan investor dalam melakukan investasi pada saham, likuiditas saham bermanfaat sebagai cerminan perkembangan kinerja perusahaan. Investor berminat melakukan pembelian saham pada perusahaan yang memiliki kinerja yang baik. Sehingga perusahaan berusaha untuk menjaga kinerjanya agar tetap baik (Wira, 2012) 
Ukuran perusahaan adalah suatu skala dimana dapat diklasifikasikan besar kecilnya perusahaaan menurut berbagai cara antara lain dengan total aktiva, penjualan bersih, dan kapitalisasi pasar perusahaan (market capitalization). Semakin besar total aktiva atau penjualan bersih perusahaan maka akan semakin besar ukuran perusahaan begitu juga sebaliknya, semakin rendah total aktiva atau penjualan bersih perusahaan maka semakin kecil pula ukuran perusahaan. Perusahaan yang memiliki total aktiva besar menunjukkan bahwa perusahaan tersebut telah mencapai tahap kedewasaan dimana dalam tahap ini arus kas perusahaan sudah positif dan dianggap memiliki prospek yang baik dalam jangka waktu yang relatif lama (Diantimala, 2008)

Ukuran perusahaan merupakan salah satu indikasi mengukur kinerja suatu perusahaan. Ukuran perusahaan yang besar dapat mencerminkan jika perusahaan mempunyai komitmen yang tinggi untuk terus memperbaiki kinerjanya, sehingga pasar akan mau membayar lebih mahal untuk mendapatkan sahamnya karena percaya akan mendapatkan pengembalian yang menguntungkan dari perusahaan tersebut (Sri, Dewi, \& Wirajaya, 2013)

Pada dasarnya perusahaan yang sudah mapan akan memiliki akses yang mudah menuju pasar modal, sementara perusahaan baru dan masih kecil akan mengalami banyak kesulitan untuk melakukan akses ke pasar modal dimana ukuran perusahaan turut menentukan tingkat kepercayaan investor, semakin besar perusahaan maka semakin dikenal oleh masyarakat (Diantimala, 2008).

Nilai buku merupakan nilai saham menurut pembukuan emiten, nilai pasar merupakan pembukuan nilai saham di pasar saham dan nilai intrinsic merupakan nilai sebenarnya dari saham. Salah satu pendekatan dalam menentukan nilai intrinsic saham adalah price book value. Price book value merupakan salah satu rasio penilaian yaitu rasio yang memberikan ukuran kemampuan manajemen menciptakan nilai pasar usahanya diatas biaya investasi dengan cara membandingkan nilai pasar saham terhadap nilai buku, dimana semakin tinggi rasio PBV dapat diartikan semakin berhasil perusahaan menciptakan nilai bagi pemegang saham, yang akan berdampak pula pada nilai perusahaan (Prasetia, Tommy, \& Saerang, 2014)

Price to book value digunakan sebagai proksi dari nilai perusahaan karena keberadaan price to book value sangat penting bagi investor untuk menentukan strategi investasi di pasar modal, bahwa perusahaan yang dikelola dengan baik pada umumnya memiliki rasio price to book value diatas satu. Hal ini menggambarkan nilai saham perusahaan lebih besar daripada nilai buku perusahaan. Harga saham yang tinggi membuat nilai perusahaan juga tinggi. Nilai perusahaan yang tinggi akan membuat pasar percaya tidak hanya pada kinerja perusahaan saat ini namun juga pada prospek perusahaan di masa depan (Prasetia et al., 2014).

Faktor tingkat perusahaan tidak hanya mempengaruhi return on investment, tapi juga likuiditas saham yang merupakan faktor penting kepada investor saat menilai saham. Karena di bawah kondisi ekonomi yang sama, likuiditas saham individu perusahaan berbeda, dampak ukuran perusahaan terhadap likuiditas saham telah menunjukkan bahwa dampak signifikan terhadap likuiditas saham dilakukan oleh kebijakan keterbukaan informasi perusahaan kepada investor (Norvaišien \& Stankevi, 2014). Adapun hipotesis pertama yang dirumuskan pada penelitian ini yaitu: 


\section{$H_{1}$ : Ukuran Perusahaan berpengaruh signifikan terhadap Likuiditas Saham.}

Nilai buku atau Price to book value digunakan sebagai proksi dari nilai perusahaan karena keberadaan price to book value sangat penting bagi investor untuk menentukan strategi investasi di pasar modal. Perusahaan yang dikelola dengan baik pada umumnya memiliki rasio price to book value diatas satu. Harga saham yang tinggi membuat nilai perusahaan juga tinggi, salah satu rasio penilaian yaitu rasio yang memberikan ukuran kemampuan manajemen menciptakan nilai pasar usahanya diatas biaya investasi dengan cara membandingkan nilai pasar saham terhadap nilai buku. Semakin tinggi rasio PBV dapat diartikan semakin berhasil perusahaan menciptakan nilai bagi pemegang saham, yang akan berdampak pula pada nilai perusahaan (Prasetia et al., 2014)

Menurut pendapat (Ang, 1997) dalam penelitian (octadianto al amiri, 2016)“seberapa jauh sebuah perusahaan mampu menciptakan nilai perusahaan relatif terhadap jumlah modal yang diinvestasikan, sehingga semakin tinggi PBV, menunjukkan semakin berhasil perusahaan menciptakan nilai bagi pemegang saham". Oleh karena itu dengan melihat PBV yang tinggi, minat investor untuk menanamkan modalnya pada peusahaan tersebut akan naik dan saham perusahaan akan sering diperdagangkan. Adapun hipotesis kedua yang dirumuskan adalah sebagai berikut:

\section{$\mathrm{H}_{2}$ : Nilai Buku berpengaruh signifikan terhadap Likuiditas Saham.}

\section{METODE PENELITIAN \\ Data dan Sampel}

Penelitian ini dilakukan pada perusahaan yang terdaftar di Bursa Efek Indonesia. Alasan pemilihan obyek ini adalah dalam pemilihan sampel tidak terdapat kendala kekurangan data, dan titik informasi yang pasti mengenai industri yang telah go publik.

Dalam penelitian ini Annual Report dan Summary digunakan sebagai sumber data utama. Jenis data yang didapatkan dari Annual Report dan Summary berupa data kuantitatif. Data kuantitatif yang digunakan seperti laporan laba rugi, laporan ekuitas, laporan neraca. Teknik pengumpulan data yang digunakan adalah dokumentasi.

Populasi pada pengamatan ini yaitu Perusahaan yang terdaftar pada Bursa Efek Indonesia di akhir periode observasi, yaitu 2017 sebanyak 539 Perusahaan. Metode pemilahan sampel pada pengamatan ini dilakukan dengan metode purposive sampling yaitu metode penarikan sampel dengan penilaian yang berdasarkan pada kategori sesuai dengan objek maupun subjek yang untuk diamati.

Kriteria untuk pengambilan sampel pada pengamatan ini yaitu :

1. Perusahaan terdaftar di BEI akhir periode Observasi, yaitu Tahun 2017.

2. Perusahaan tidak terdaftar di BEI berturut-turut selama periode Observasi (2013-2017).

3. Perusahaan terdaftar di BEI yang Tidak menerbitkan Laporan Keuangan selama periode observasi (2013-2017).

4. Perusahaan yang tidak menyediakan data keuangan sesuai Variable yang diuji yaitu Likuiditas Saham, Ukuran Perusahaan, Nilai Buku. 
berikut:

Berdasarkan kriteria-kriteria tersebut, maka diperoleh sampel pada Tabel

\section{Tabel 1}

Tabulasi Pengambilan Sampel Menggunakan Purposive Sampling

\begin{tabular}{clc}
\hline No & \multicolumn{1}{c}{ Kiteria } & Jumlah \\
\hline 1 & $\begin{array}{l}\text { Perusahaan terdaftar di BEI akhir periode Observasi, yaitu } \\
\text { Tahun 2017. }\end{array}$ & 539 \\
2 & $\begin{array}{l}\text { Perusahaan tidak terdaftar di BEI berturut-turut selama } \\
\text { periode Observasi (2013-2017). }\end{array}$ & (142) \\
3 & $\begin{array}{l}\text { Perusahaan terdaftar di BEI yang Tidak menerbitkan } \\
\text { Laporan Keuangan selama periode observasi (2013-2017). }\end{array}$ & (113) \\
& $\begin{array}{l}\text { Perusahaan yang tidak menyediakan data keuangan sesuai } \\
\text { Variable yang diuji Yaitu Likuiditas Saham, Ukuran } \\
\text { Perusahaan, Nilai Buku. }\end{array}$ & \multicolumn{3}{c}{ (185) } \\
\hline \multicolumn{4}{c}{ Jumlah Sampel Akhir } \\
\hline
\end{tabular}

Sumber : Diolah Peneliti, 2018

\section{Definisi Operasional Variabel}

Dalam penelitian ini terdiri dari dua macam variabel yaitu variabel independent dan dependent. Variabel independent yaitu Ukuran Perusahaan $\left(\mathrm{X}_{1}\right)$, Nilai Buku $\left(\mathrm{X}_{2}\right)$. Variabel dependent yaitu Likuiditas Saham (Y). Selanjutnya dapat diuraikan definisi operasionalnya dari pengamatan ini sebagai berikut:

\section{Tabel 2}

Definisi Operasional Variabel

\begin{tabular}{|c|c|c|c|c|}
\hline No & Variabel & Definisi & Pengukuran & Sumber \\
\hline 1 & $\begin{array}{l}\text { Likuiditas } \\
\text { Saham (Y) }\end{array}$ & $\begin{array}{l}\text { Bid-ask spread adalah } \\
\text { perbandingan antara } \\
\text { harga jual saham (yang } \\
\text { diwakilkan dengan } \\
\text { harga tertinggi closing } \\
\text { price) dikurang harga } \\
\text { beli saham (yang } \\
\text { diwakilkan dengan } \\
\text { harga terendah closing } \\
\text { price) dengan harga } \\
\text { jual saham }\end{array}$ & $\begin{array}{l}\text { Bid-ask Spread } \\
=\frac{\text { High-low }}{\text { high }} \mathrm{x} \\
100 \%\end{array}$ & $\begin{array}{l}\text { (Norvaiši } \\
\text { en \& } \\
\text { Stankevi, } \\
\text { 2014) }\end{array}$ \\
\hline 2 & $\begin{array}{c}\text { Ukuran } \\
\text { Perusahaan } \\
\left(\mathrm{X}_{1}\right)\end{array}$ & $\begin{array}{l}\text { Untuk menentukan } \\
\text { ukuran perusahaan } \\
\text { adalah dengan log } \\
\text { natural dari total } \\
\text { aktiva. }\end{array}$ & $\begin{array}{l}\text { Size }=\text { Ln of total } \\
\text { aktiva }\end{array}$ & $\begin{array}{l}\text { (Prasetia } \\
\text { et al., } \\
2014)\end{array}$ \\
\hline
\end{tabular}




\begin{tabular}{cclcc}
\hline No & Variabel & \multicolumn{1}{c}{ Definisi } & Pengukuran & Sumber \\
\hline 3 & Nilai Buku & Price to book value & & \\
& $(\mathrm{X} 2)$ & (PBV) adalah rasio & PBV = Harga Pasar & (Arista \& \\
& yang digunakan & persaham /Nilai Buku & Astohar, \\
& untuk mengukur & persaham & 2012) \\
& kinerja harga pasar & & \\
& saham terhadap & & \\
& nilai bukunya. PBV & & \\
& adalah indikator & & \\
& lain yang digunakan & & \\
& untuk menilai & & \\
& kinerja perusahaan. & & \\
& (Arista \& Astohar, & & \\
& 2012) &
\end{tabular}

\section{Teknik Analisis Data}

Dalam penelitian ini dilakukan pengujian hipotesis yang bertujuan menguji pengaruh ukuran perusahaan, nilai buku terhada likuiditas saham. Dalam penelitian ini data yang digunakan yaitu data panel, yang merupakan gabungan antara data time series dan cross section. Data sampel sebanyak 99 perusahaan diambil dari data unit cross section dan data time series periode 2013-2017.

Analisis statistik deskriptif merupakan metode analisis yang digunakan dalam penelitian ini dan menggunakan Program Eviews (Winarno, 2015) untuk analisi regresi data panel. Persamaan regresi data panel yang digunakan dalam penelitian ini adalah:

\section{$\mathrm{LS}_{\mathrm{it}}=\alpha+\beta_{1}$ SIZEit $+\beta_{2}$ PBVit $+\mathrm{e}$}

Dimana LSit merupakan Likuiditas Saham pada waktu t, $\alpha$ merupakan konstanta (intercept), $\beta 1, \beta 2$ merupakan Koefisien Regresi, SIZEit merupakan Ukuran Perusahaan pada waktu t, PBVit merupakan Nilai Buku pada waktu t, dan e merupakan Standar error.

Pendekatan yang dilakukan dalam analisis regresi data panel yaitu common effect model (CEM), Fixed effect Model (FEM), random effect model ( REM) (Wulandari, 2017). Ada dua tahapan yang dilakukan untuk menentukan model yang terbaik digunakan antara model tersebut yaitu: Uji Chow, untuk menentukan model mana yang terbaik antara common effect model (CEM) dengan Fixed effect Model (FEM). Uji Hausman, dilakukan untuk menentukan model mana yang terbaik digunakan antara Fixed effect Model (FEM) dengan random effect model ( REM). Model regresi yang baik harus menghasilkan estimasi linear tidak bias (Best Linear Unbiased Estimator).

HASIL DAN PEMBAHASAN

Uji Statistik Deskriptif Variabel

Tabel 4

Hasil Uji Statistik Deskriptif

Variabel Minimum $\quad$ Maksimum $\quad$ Mean $\quad$ Standar




$\begin{array}{lllll}\text { Liukiditas Saham } & 11.29000 & 98.29000 & 47.40055 & 17.90055 \\ \text { Ukuran Perusahaan } & 11.21000 & 22.56000 & 15.40881 & 1.718139 \\ \text { Nilai Buku } & 0.010000 & 82.44000 & 2.714848 & 6.232210\end{array}$

Sumber : data diolah, Eviews 8

Pada tabel 4 menunjukkan angka-angka deskriptif dari masing-masing variabel dengan jumlah observasi sebanyak 495 (empat ratus sembilan puluh lima). Penjelasan dari analisis deskriptif adalah sebagai berikut :

Likuiditas Saham merupakan variabel terikat dengan menggunakan Bid ask spread sebagai alat ukur dapat dilihat nilai minimum sebesar 11.29 yang terdapat di perusahaan Firs Media Tbk tahun 2013 dan nilai maximum sebesar 98.29 yang terdapat di perusahaan Pelat Timah Nusantara Tbk tahun 2016. Sedangkan nilai rata-rata (mean) data Likuiditas Saham sebesar 47.40, nilai ini berarti perubahan harga relatif (jual-beli) saham lebih tinggi dibandingkan harga jual dan nilai standar deviasi sebesar 17.90.

Ukuran perusahaan merupakan variabel bebas yang menggunakan Logaritma natural dari total aset sebagai alat ukurnya. Nilai minimum size sebesar 11.21 menunjukan logaritma natural dari total aset perusahaan yang diperoleh oleh PT Indosat Tbk tahun 2017. Nilai maximum size sebesar 22.56 menunjukan logaritma dengan basis euler dari total aset perusahaan yang diperoleh oleh Perusahaan Gas Negara (Persero) Tbk tahun 2017. Nilai rata-rata ukuran perusahaan sebesar 15.41 menunjukan logaritma natural dari total aset perusahaan. Nilai standar deviasi dari ukuran perusahaan sebesar 1.72 yang menunjukkan penyebaran data lebih kecil karena nilainya lebih rendah dari nilai rata-rata (mean).

Nilai Buku merupakan variabel bebas dengan menggunakan PBV sebagai alat ukur, dapat dilihat nilai minimum 0.01 yang diperoleh Indo Kordsa Tbk pada tahun 2016 dan nilai maximum sebesar 82.44 yang diperoleh Unilever Indonesia Tbk pada tahun 2017. Nilai rata-rata (mean) Earning Price to Book Value sebesar 2.71 menunjukan kemampuan perusahaan memperoleh Nilai buku dengan membandingkan harga perlembar saham dengan nilai buku perlembar saham. Pada Nilai Buku didapatkan hasil standar deviasi sebesar 6.23, yang berarti tingkat keragaman sampel memiliki kesamaan yang tinggi antar sampel.

\section{Pemilihan Regresi Data Panel}

Dalam data panel untuk pemilihan model yang terbaik dilakukan tahap analisis dengan cara melakukan estimasi model Common Effect (CEM), Fixed Effect (FEM), dan Random Effect (REM). Persamaan regresi likuiditas dengan menggunakan proksi current ratio adalah sebagai berikut:

$$
\operatorname{LogLSit}=\alpha+\beta 1 \text { SIZEit }+\beta 2 \operatorname{LogPBVit}+\text { eit }
$$

Persamaan ini menggunakan transformasi logaritma dalam menentukan model yang terbaik. Hasil statistik yang diperoleh dalam pengestimasian model CEM, FEM, dan REM adalah sebagai berikut:

Tabel 5

Tabel Estimasi CEM, FEM, dan REM

\begin{tabular}{llll}
\hline Variabel Common Effect & Fixed Effect & Random Effect \\
\hline
\end{tabular}




\begin{tabular}{crccccc}
\hline & t-statistik & prob & t-statistik & prob & t-statistik & prob \\
\hline C & 23.92927 & 0.0000 & 7.002180 & 0.0000 & 21.62231 & 0.0000 \\
LN & -0.542410 & 0.5878 & 1.767166 & 0.0780 & -0.361927 & 0.7176 \\
LPBV & -3.231052 & 0.0013 & 2.483856 & 0.0134 & -2.435690 & 0.0152 \\
\hline
\end{tabular}

Sumber : data diolah, Eviews 8

Tabel 5 menunjukkan hasil estimasi menjelaskan bahwa masing-masing model memiliki nilai signifikansi yang berbeda-beda. Untuk menemukan model mana yang terbaik maka dilakukan analisis lebih lanjut dengan menggunakan Uji Chow dan Hausman Test.

\begin{tabular}{lrrr} 
& $\begin{array}{c}\text { Tabel 6 } \\
\text { Uji chow } \\
\text { Effects Test }\end{array}$ & & \\
Statistic & d.f. & Prob. \\
\hline \hline Cross-section F & 1.631776 & $(98,394)$ & 0.0006 \\
Cross-section Chi-square & 168.626059 & 98 & 0.0000 \\
\hline \hline
\end{tabular}

Uji chow bertujuan untuk menentukan model yang lebih baik digunakan antara model Common Effect dan Fixed Effect. Berdasarkan tabel di atas diperoleh nilai prob pada Cross-section Chi-square lebih kecil dari alpha $(\alpha)(0.0000<0.05)$, maka H0 ditolak. Artinya model Fixed Effect lebih baik digunakan dari model Common Effec.

Tabel 7

Uji Hausman

Chi-Sq.

Test Summary Statistic Chi-Sq. d.f. Prob.

\begin{tabular}{llll}
\hline \hline Cross-section random & 20.432430 & 2 & 0.0000 \\
\hline \hline
\end{tabular}

Uji Hausman bertujuan untuk menentukan model yang lebih baik antara model Fixed Effect dan model Random Effect. Tabel 7 menunjukkan bahwa nilai prob pada Cross-section random lebih kecil dari alpha $(\alpha)(0.0000<0.05)$, maka H0 ditolak. Artinya model Fixed Effect lebih baik digunakan dari model random Effect'

\section{Uji Asumsi Klasik} berikut:

Hasil uji normalitas dengan uji statistik Jarque-Bera tergambar pada grafik 


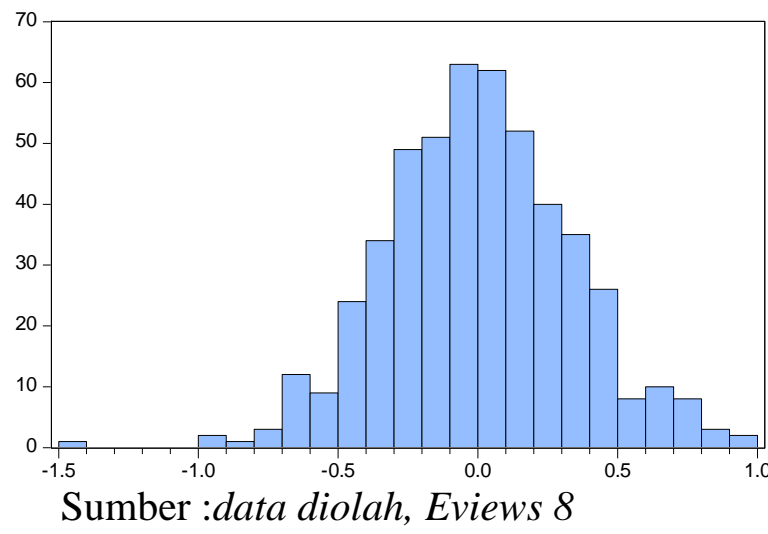

Berdasarkan Gambar 1 diatas, hasil pengujian normalitas data menunjukkan nilai probability lebih besar dari alpha $(0.109>0.05)$ maka dapat dikatakan bahwa residual dalam model penelitian ini telah berdistribusi normal.

\section{Analisis Regresi Data Panel}

Dalam penelitian ini teknik analisis data digunakan untuk mengolah, membahas sampel yang sudah diperoleh dan untuk menilai hipotesis yang diduga. Variabel C merupakan constant (konstan), Likuiditas saham merupakan variabel terikat $(\mathrm{Y})$, Ukuran perusahaan merupakan variabel bebas $\left(\mathrm{X}_{1}\right)$, dan Nilai buku merupakan variabel bebas $\left(\mathrm{X}_{2}\right)$.

Regresi data panel digunakan sebagai metode analisa untuk data time series dan cross section. Hasil estimasi model regresi data panel dapat disajikan dalam tabel berikut:

Tabel 8

Tabel Hasil Estimasi Regresi Data Panel

\begin{tabular}{|c|c|c|}
\hline Variabel & Koefisien & t-Statistic \\
\hline Konstanta (C) & 3.0023 & 7.002180 \\
\hline $\begin{array}{c}\text { Ukuran Perusahaan } \\
(\mathrm{LN})\end{array}$ & 0.0490 & 1.767166 \\
\hline Nilai Buku (LPBV) & 0.0896 & 2.483856 \\
\hline
\end{tabular}

Sumber: data diolah, Eviews 8

Persamaan Regresi Data Panel Fixed Effect Model adalah sebagai berikut:

$$
\mathrm{LS}=3.0023+0.0490 \mathrm{LNit}+0.0896 \mathrm{LPBVit}
$$

Angka pada Persamaan Regresi Data Panel didapatkan dari nilai coefficient variabel. Nilai konstanta sebesar 3.0023 ini menjelaskan jika diasumsikan nilai variabel independen bernilai 0.000 maka nilai Likuiditas Saham bernilai tetap sebesar 3.0023. Koefisien Ukuran Perusahaan (LN) sebesar 0.0490 artinya setiap peningkatan variabel Ukuran Perusahaan sebanyak 1 satuan berarti akan 
meningkatkan variabel Likuiditas Saham sebanyak 0.0490 serta beranggapan variabel lain dalam bentuk konstan. Koefisien Nilai buku sebesar 0.0896 artinya setiap peningkatan variabel Nilai Buku sebanyak 1 satuan berarti akan menurunkan variabel Likuiditas Saham sebanyak 0.0896 serta beranggapan variabel lain dalam bentuk konstan..

\section{Hasil Pengujian Hipotesis}

Uji hipotesis ini bertujuan untuk mengetahui hubungan signifikan dari variabel Ukuran Perusahaan (LN) dan Nilai Buku ke variabel Likuiditas Saham. Uji statistik menunjukkan seberapa besar pengaruh suatu variabel independen terhadap variabel dependen, dilakukan untuk memeriksa lebih lanjut apakah variabel Ukuran Perusahaan dan Nilai buku tersebut signifikan atau tidak terhadap variabel Likuiditas Saham. Kriteria pengujian berupa jika nilai probability Thitung lebih besar Ttabel maka $\mathrm{H} 0$ ditolak dan Ha diterima dan jika nilai probability Thitung lebih kecil Ttabel maka Ha ditolak dan H0 diterima. Dengan tingkat signifikansi sebesar 0.05 (5\%).

Pada tabel 8 untuk variabel Ukuran Perusahaan dengan menggunakan indikator LN secara absolut menunjukkan nilai Thitung lebih kecil dari Ttabel $(1.767166<1.964787)$ atau probability lebih besar dari alpha $(0.0780>0.05)$ maka Hipotesis pertama $(\mathrm{H} 1)$ dalam penelitian ditolak. Untuk variabel Nilai buku secara absolut menunjukkan nilai Thitung lebih besar dari Ttabel (2.483856>1.964787) atau probability lebih kecil dari alpha $(0.0134<0.05)$ maka Hipotesis kedua $(\mathrm{H} 2)$ diterima. Maka disimpulkan bahwa Ukuran Perusahaan berpengaruh positif dan tidak signifikan terhadap Likuiditas Saham dan Nilai buku berpengaruh signifikan terhadap Likuiditas Saham.

\section{PEMBAHASAN}

\section{Pengaruh Ukuran Perusahaan Terhadap Likuiditas Saham}

Penelitian yang dilakukan terhadap 99 data observasi yang diperoleh dari data perusahaan di Bursa Efek Indonesia (BEI) selama periode 2013-2017. Data tersebut diseleksi menggunakan beberapa kriteria yang telah ditetapkan. Dari hasil estimasi dengan menggunakan program eviews 8 dapat disimpulkan bahwa Ukuran Perusahaan sebagai hipotesis 1 (H1) yang menyatakan bahwa Ukuran Perusahaan tidak berpengaruh signifikan terhadap Likuiditas Saham. Artinya besar/kecilnya Ukuran Perusahaan, maka tidak akan berpengaruh terhadap Likuiditas Saham.

Hal ini dikarenakan bahwa naik turunnya tingkat Likuiditas Saham, tidak dipengaruhi oleh ukuran perusahaan. Dalam arti kata ukuran perusahaan tidak terkontribusi terhadap Likuiditas saham. Secara operasional, Likuiditas saham tidak ditentukan oleh LN of total aktiva yang terdapat dalam ukuran perusahaan. Sedangkan ukuran perusahaan tidak ditentukan oleh harga jual dan harga beli saham.

Selain itu, hal ini bisa disebabkan oleh banyaknya data yang tereliminasi pada waktu penyeleksian data yang telah dilakukan karena banyaknya data yang outliers. Banyak data outliers (ekstrem) dikarenakan perusahaan yang dijadikan sebagai sampel berasal dari sektor yang berbeda.

\section{Pengaruh Nilai Buku Terhadap Likuiditas Saham}


Rasio PBV merupakan rasio penilaian investor terhadap nilai buku perusahaan. Dari hasil penelitian, diperoleh koefisien PBV sebesar 0.0896 dengan nilai signifikan 0.0134. Ini berarti bahwa jika investor memandang suatu perusahaan memiliki nilai yang baik, maka investor akan melakukan transaksi perdagangan saham. Selama periode penelitian, rasio PBV memiliki pengaruh yang signifikan secara statistik (nilai signifikan $<0.05$ ) terhadap frekuensi perdagangan saham. Berarti Likuiditas Saham akan meningkat, jika investor menilai bahwa harga pasar saham lebih besar dari nilai bukunya.

Hal ini sesuai dengan pendapat (Ang, 1997) dalam penelitian (octadianto al amiri, 2016)“seberapa jauh sebuah perusahaan mampu menciptakan nilai perusahaan relatif terhadap jumlah modal yang diinvestasikan, sehingga semakin tinggi PBV, menunjukkan semakin berhasil perusahaan menciptakan nilai bagi pemegang saham". Oleh karena itu dengan melihat PBV yang tinggi, minat investor untuk menanamkan modalnya pada peusahaan tersebut akan naik dan saham perusahaan akan sering diperdagangkan.

\section{SIMPULAN}

Hasil dari penelitian Dampak Ukuran Perusahaan (LN) dan Nilai Buku (PBV) terhadap Likuiditas Saham dapat disimpulkan sebagai berikut :

1. Ukuran Perusahaan tidak berpengaruh signifikan terhadap Likuiditas Saham pada perusahaan yang terdaftar di Bursa Efek Indonesia periode 2013-2017. Artinya besar/kecilnya Ukuran Perusahaan tidak berpengaruh terhadap tingkat perubahaan harga jual-beli saham.

2. Nilai Buku (PBV) berpengaruh signifikan terhadap Likuiditas Saham pada perusahaan yang terdaftar di Bursa Efek Indonesia periode 2013-2017. Artinya, seberapa jauh sebuah perusahaan mampu menciptakan nilai perusahaan relatif terhadap jumlah modal yang diinvestasikan, sehingga semakin tinggi PBV, menunjukkan semakin berhasil perusahaan menciptakan nilai bagi pemegang saham.

\section{UCAPAN TERIMA KASIH}

Selesainya penulisan ini, karena penulis banyak menerimamasukan dan dorongan baik motivasi secara moral atau spiritual. Oleh karena itu penulis ingin mengucapkan terimakasih kepada:

1. Bapak Febryandhie Ananda, SE, Msi. selaku ketua STIE"KBP” Padang

2. Ibu Febsri Susanti, SEI, MM. selaku ketua Program Studi Manajemen

3. Bapak Irdha Yusra SE, MSc. sebagai dosen pembimbing dalam pembuatan skripsi ini dan penulis banyak berterima kasih atas kesabaran, kepedulian dan kesempatan yang sudah diberikan, penulis berharap kebaikan bapak bisa dibalas oleh Tuhan Yang Maha Esa

4. Seluruh bagian yang sudah banyak menolong penulis yang tidak dapat penulis sampaikan satu persatu.

\section{DAFTAR PUSTAKA}

Arista, D., \& Astohar. (2012). Analisa Faktor - Faktor Yang Mempengaruhi Return Saham (Kasus pada Perusahaan Manufaktur yang Go Public di BEI Periode Tahun 2005 - 2009). Jurnal Ilmu Manajemen Dan Akuntansi Terapan, 3, 1- 
15.

Diantimala, Y. (2008). Pengaruh Akuntansi Konsevatif, Ukuran Perusahaan Dan Default Risk, 1(1), 102-122.

Lestari, S., \& Sudaryono, A. (2008). Pengaruh Stock Split: Analisis Likuiditas Saham Pada Perusahaan Go Public Di Bursa Efek Indonesia Dengan Memperhatikan Pertumbuhan Dan Ukuran Perusahaan, 10(3), 139-148.

Mulyana. (2011). Diterbitkan pada JURNAL Magister Manajemen Volume 4 Nomor 1 Maret, 4, 1-14.

Norvaišien, R., \& Stankevi, J. (2014). Impact of companies' internal factors on stock liquidity in Baltic markets, 156(April), 543-547. https://doi.org/10.1016/j.sbspro.2014.11.237

octadianto al amiri, laila nifsul. (2016). Roa dan PBV serta pengaruhnya terhadap Likuiditas Saham perusahaan real estate di jakarta islamic index, 27-38.

Prasetia, T. E., Tommy, P., \& Saerang, S. I. (2014). 3 1, 2, 3, 2(2), 879-889.

Sri, A., Dewi, M., \& Wirajaya, A. (2013). Pengaruh struktur modal, 2, 358-372.

Winarno, wing wahyu. (2015). Analisis Ekonometrika dan Statistika dengan Eviews (4th ed.). Yogyakarta: Upp Stim Ykpn.

Wira, V. (2012). Analisis Kinerja Keuangan Perusahaan Terhadap Likuiditas Saham Pada Perusahaan Yang Listing Di Bursa Efek Indonesia, 7.

Wulandari, N. (2017). Analisis Faktor-Faktor yang Mempengaruhi Inflasi pada Kota Metropolitan di Indonesia dengan Menggunakan Analisis Data Panel, $3(2), 34-42$.

Edit identitas dimendeley pada nama yang dimerahkan. 